\title{
Synthesis, Characterization and Preliminary Study on Acetylpyrazine N(4)Butylthiosemicarbazone as a Potential CDK2 Inhibitor Combined with DFT Calculations
}

\author{
Erna Normaya, *,a Mohammad N. Ahmad, ${ }^{a}$ Yang Farina ${ }^{b}$ and Ku H. K. Bulat ${ }^{c}$ \\ ${ }^{a}$ Experimental and Theoretical Research Laboratory, Department of Chemistry, \\ Kulliyyah of Science, International Islamic University Malaysia, 25200 Kuantan, Pahang, Malaysia \\ ${ }^{b}$ School of Chemical Sciences and Food Technology, Faculty of Science and Technology, \\ Universiti Kebangsaan Malaysia, 43600 Bangi, Selangor, Malaysia \\ ${ }^{c}$ Department of Chemistry, Faculty of Science, Universiti Malaysia Terengganu, Mengabang Telipot, \\ 21030 Kuala Terengganu, Terengganu Darul Iman, Malaysia
}

\begin{abstract}
In this study, a new thiosemicarbazone ligand, namely acetylpyrazine N(4)butylthiosemicarbazone (APBT), was synthesized and characterized using ${ }^{1} \mathrm{H}$ and ${ }^{13} \mathrm{C}$ nuclear magnetic resonance (NMR) and Fourier transform infrared (FTIR) spectroscopies. Quantum chemical calculations were performed using density functional theory at the B3LYP/6-311++G(d,p) basis set level. The optimized molecular geometry of APBT is discussed based on X-ray structural reports from the literature. The assignment of the vibrational frequencies was done based on a potential energy distribution analysis using the vibrational energy distribution analysis (VEDA) 4 software. The energy gap between the highest occupied molecular orbital (HOMO) and lowest unoccupied molecular orbital (LUMO) was evaluated to study the reactivity and stability of the compound. Global chemical reactivity and local reactivity descriptors of reactants and the product (APBT) were calculated to study the reaction mechanism. The region of interaction during the reaction to form APBT was determined using molecular electrostatic potential analysis. Finally, a preliminary study of the title compound as a cyclin-dependent kinase (CDK) inhibitor was further evaluated by performing a docking calculation.
\end{abstract}

Keywords: thiosemicarbazone, DFT, global reactivity descriptors, CDK inhibitor

\section{Introduction}

Thiosemicarbazones and their derivatives have shown significant interest in areas of chemistry and biology. ${ }^{1}$ The thiosemicarbazone ligand itself can be used for metal analysis, ${ }^{2}$ for device applications related to telecommunications, optical computing, storage and information processing. ${ }^{3}$ Thiosemicarbazones are versatile compounds that exist as three structural isomers $\left(E, E^{\prime}\right.$ and $Z)^{4}$ and can coordinate to a metal either as a neutral ligand or as a deprotonated ligand. ${ }^{5}$ The common thiosemicarbazone ligand acts as a bidentate ligand through the azomethine nitrogen and thiocarbonyl sulfur atom. The ligand can bind in a multidentate fashion when the $\mathrm{N} 1$ position of the thiosemicarbazone moiety is substituted with a carbon $\alpha$ to an aldehyde or ketone group that has atoms of different

*e-mail: ernanormaya@gmail.com electronegativity. The presence of a $\mathrm{NH}-\mathrm{C}=\mathrm{S}$ group results in tautomerism of the thiosemicarbazone to form a thione or thiol. ${ }^{6}$ Moreover, thiosemicarbazones have shown a wide spectrum of biological properties, including antibacterial, ${ }^{7}$ antifungal, ${ }^{8}$ and anticancer. ${ }^{9}$ Cancer still remains one of the most feared diseases and a major cause of death in the modern world. Cyclin-dependent kinases (CDKs) as controllers in the cell cycle are overexpressed and overactive in many cancer cells. Ongoing study is being undertaken to find effective CDK inhibitors to overcome this problem.

In this study, the potential of the title compound was used to study the cyclin-dependent kinase 2 (CDK2) protein receptor activity, which is one of the CDK family, by using in silico calculations. The CDK2 inhibitor is involved in anticancer treatment for lung cancer. ${ }^{10}$ The unique properties of thiosemicarbazone ligands as a potential CDK2 inhibitor led us to the aim of the present work: to characterize in 
detail the chemical properties of thiosemicarbazone ligands using the density functional theory (DFT) method. The DFT functions act in a semi-empirical fashion to account for the electron correlation and have been extended to include other corrections such as dispersion. ${ }^{11}$ Using this method, the highest occupied molecular orbital (HOMO) and lowest unoccupied molecular orbital (LUMO) energies were calculated to characterize global chemical reactivity parameters such as the chemical potential $(\mu)$, hardness $(\eta)$, softness (s), electronegativity $(\chi)$ and electrophilic index $(\omega)$. In addition, Fukui functions were used to explain the selectivity of each atom in the reaction to become an electrophile or a nucleophile in the reaction mechanism. The data from the calculation was used to evaluate the correlations between experiment and theory for the Fourier transform infrared (FTIR) spectroscopy. The optimized structure using DFT calculation was further used to study the potential of the title compound against the CDK2 macromolecule as anticancer therapeutic using a computational drug design approach.

\section{Results and Discussions}

${ }^{1} \mathrm{H}$ and ${ }^{13} \mathrm{C}$ nuclear magnetic resonance (NMR) spectroscopies

Proton and carbon NMR spectroscopies are helpful and powerful tools for identification of organic compounds in conjunction with other spectrometric information, in addition to X-ray crystallography. Recrystallization from various solvents was attempted to produce single crystals. However, it was unsuccessful. Figure S1 (Supplementary Information (SI) section) shows the numbering used for assignment of ${ }^{1} \mathrm{H}$ and ${ }^{13} \mathrm{C}$ NMR chemical shift signals for $\mathrm{N}(4)$ butylthiosemicarbazone (APBT). The characterization of APBT was carried out in deuterated dimethyl sulfoxide (DMSO- $d_{6}$ ) solution using tetramethylsilane (TMS) as an internal standard. The data collected is presented in Table 1. The two proton signals of $\mathrm{N}(20)$ and $\mathrm{N}(16)$ were observed at $\delta 10.13$ and $9.79 \mathrm{ppm}$, respectively, confirming that the ligand form is a thione compound. The most shielded proton, appearing as a triplet signal at $\delta 0.54 \mathrm{ppm}$, corresponds to the methyl group from $\mathrm{C}(31)$. The signal of the protons from the methyl group $\mathrm{C}(11)$ was identified as a single signal at $\delta 2.50 \mathrm{ppm}$. In the ${ }^{13} \mathrm{C}$ NMR spectrum, the most downfield signal, appearing at $\delta 170.38 \mathrm{ppm}$, corresponds to the $\mathrm{C}(18)$ atom, while the signal of carbon $\mathrm{C}(10)$ appeared at $\delta 145.88 \mathrm{ppm}$. The $\mathrm{C}(10)$ signal was shielded compared with the $C(18)$ because $C(18)$ are bonded to the two nitrogen and sulfur, while $C(10)$ are bonded to the two carbon and nitrogen atoms, respectively.
The signal of the most shielded carbon atom, appearing at $\delta 12.34 \mathrm{ppm}$, corresponds to the methyl group of $\mathrm{C}(31)$.

Table 1. ${ }^{1} \mathrm{H}$ and ${ }^{13} \mathrm{C}$ NMR data of APBT

\begin{tabular}{lc}
\hline APBT & Chemical shift / ppm \\
\hline $\mathrm{N}(16)-\mathrm{H}$ & $10.13(\mathrm{~s}, 1 \mathrm{H})$ \\
$\mathrm{N}(20)-\mathrm{H}$ & $9.79(\mathrm{~s}, 1 \mathrm{H})$ \\
$\mathrm{C}(5)-\mathrm{H}$ & $9.65(\mathrm{~s}, 1 \mathrm{H})$ \\
$\mathrm{C}(2)-\mathrm{H}$ & $8.62(\mathrm{~d}, 2 \mathrm{H})$ \\
$\mathrm{C}(11)-\mathrm{H}$ & $2.50(\mathrm{~s}, 3 \mathrm{Hs})$ \\
$\mathrm{C}(22)-\mathrm{H}$ & $1.70(\mathrm{t}, 2 \mathrm{H})$ \\
$\mathrm{C}(28)-\mathrm{H}$ & $1.48(\mathrm{~m}, 2 \mathrm{H})$ \\
$\mathrm{C}(25)-\mathrm{H}$ & $1.39(\mathrm{~m}, 2 \mathrm{H})$ \\
$\mathrm{C}(31)-\mathrm{H}$ & $0.54(\mathrm{t}, 3 \mathrm{H})$ \\
$\mathrm{C} 18$ & 170.38 \\
$\mathrm{C} 4$ & 150.99 \\
$\mathrm{C} 5$ & 150.70 \\
$\mathrm{C} 10$ & 145.88 \\
$\mathrm{C} 2$ & 144.77 \\
$\mathrm{C} 1$ & 143.95 \\
$\mathrm{C} 22$ & 30.99 \\
$\mathrm{C} 25$ & 19.88 \\
C28 & 18.35 \\
C11 & 13.11 \\
C31 & 12.34 \\
\hline APB & \\
\hline
\end{tabular}

APBT: N(4)butylthiosemicarbazone.

\section{Molecular geometry}

The optimized structure of APBT calculated using Becke, 3-parameter, Lee-Yang-Parr (B3LYP) 6-311++G(d,p) basis set is shown in Figure 1. Comparison between selected bond lengths and bond angles was made with the other $\mathrm{X}$-ray crystallographic structure ${ }^{12}$ (Cambridge Structural Database (CSD) No. 820252) from a similar system since the crystal structure of this compound is not available. The experimental and calculated geometric parameters of APBT are listed in Table S1 (SI section). The calculated bond length of $\mathrm{C}-\mathrm{S}$ was $1.681 \AA$, while the experimental data provided $1.680 \AA$. The calculated and experimetal data showed the bond length was assigned to the double bond character of $\mathrm{C}-\mathrm{S}$ in a thione compound..$^{13,14}$ For the thiosemicarbazone moiety, the bond length of C10-N15 was $1.296 \AA$, while the experimental data provided $1.284 \AA$, with differences assigned to the double bond character as well. ${ }^{15}$ Due to the tautomerization around S19-C18-N20, the calculated and experimetal bond length of $\mathrm{C} 18-\mathrm{N} 20$ is slightly shorter compared to the $\mathrm{C} 18-\mathrm{N} 16$ with values of 1.343 and 1.337 , and 1.386 and $1.373 \AA$, respectively. The selected single bonds were $\mathrm{C} 4-\mathrm{C} 10, \mathrm{C} 10-\mathrm{C} 11, \mathrm{~N} 15-\mathrm{N} 16$, and $\mathrm{N} 20-\mathrm{C} 22$, calculated as $1.481,1.506,1.349$, and 


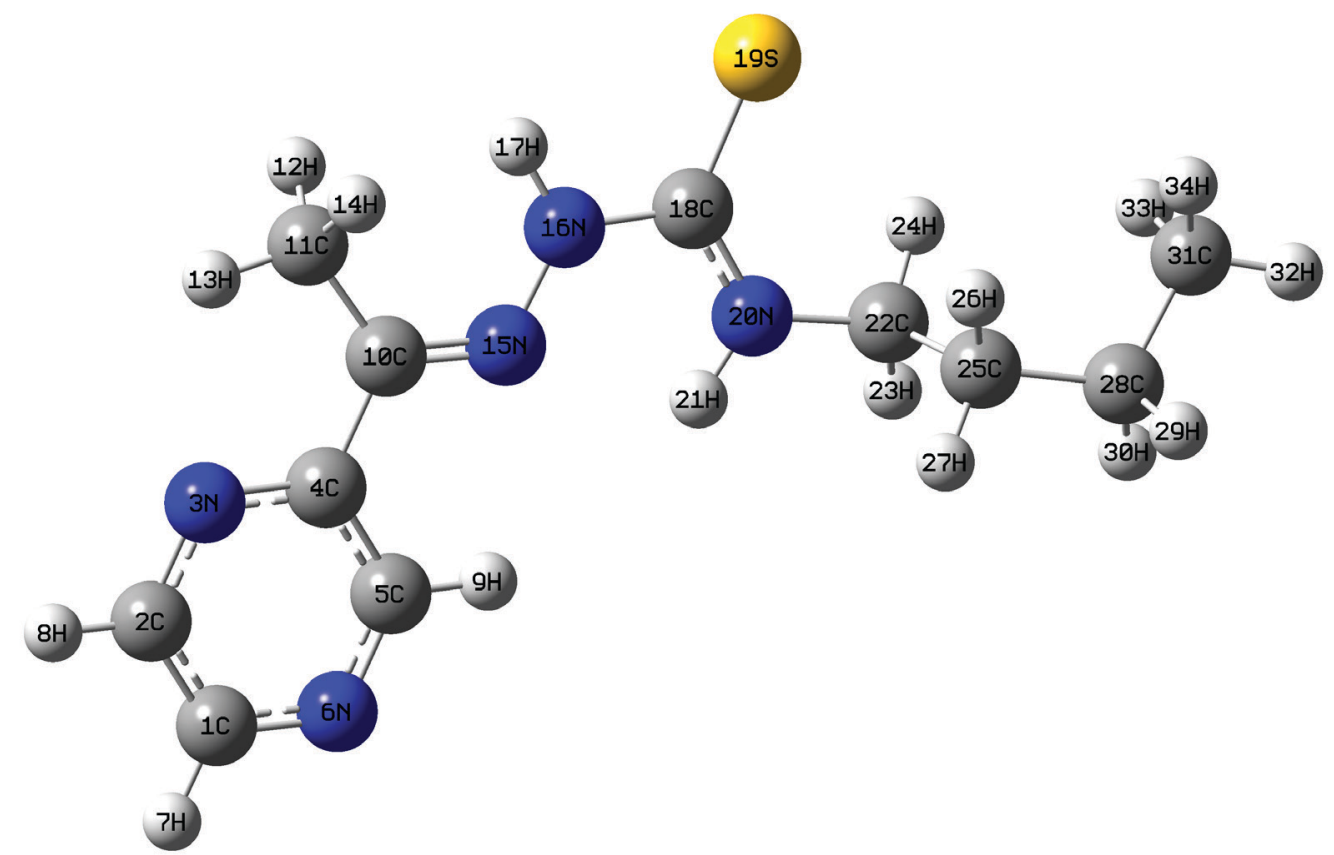

Figure 1. The optimized molecular structure of APBT.

$1.409 \AA$, respectively; the experimental data provided $1.485,1.500,1.366$, and $1.409 \AA$, respectively. The value of correlation coefficient $\left(R^{2}=0.97639\right)$ shown in Figure $S 2$ (SI section) also confirmed that there is a good agreement between experimental and calculated results. The slightly deviated geometric parameters between the calculated and experimental data are likely due to the fact that the theoretical calculations were made on the molecule in the gas state/in a vacuum while the experimental results were for the solid state. ${ }^{16}$

\section{Vibrational analysis}

The experimental IR spectrum and the calculated data using B3LYP/6-311++G(d,p) are shown in Figure 2. For comparison, the scaled calculated harmonic vibrational frequencies at the B3LYP/6-311++G(d,p) level, the selected data between experimental and theoretical vibrational frequencies, and the details of the percentage of potential energy distribution (PED) assignment have been tabulated in Table 2.

\section{$\mathrm{N}-\mathrm{H}$ vibrations}

The two $\mathrm{N}-\mathrm{H}$ stretching vibrations observed occurred at 3363 and $3219 \mathrm{~cm}^{-1},{ }^{17,18}$ while the calculated theoretical values were found to be 3453 and $3438 \mathrm{~cm}^{-1} .{ }^{19}$ Based on the results of the PED analysis shown in Table 3, the N-H bending vibrations were found at 1529, 1484, 1341 and $1279 \mathrm{~cm}^{-1} .{ }^{20}$ In the experimental data, the only vibration found was at $1470 \mathrm{~cm}^{-1} .^{21}$

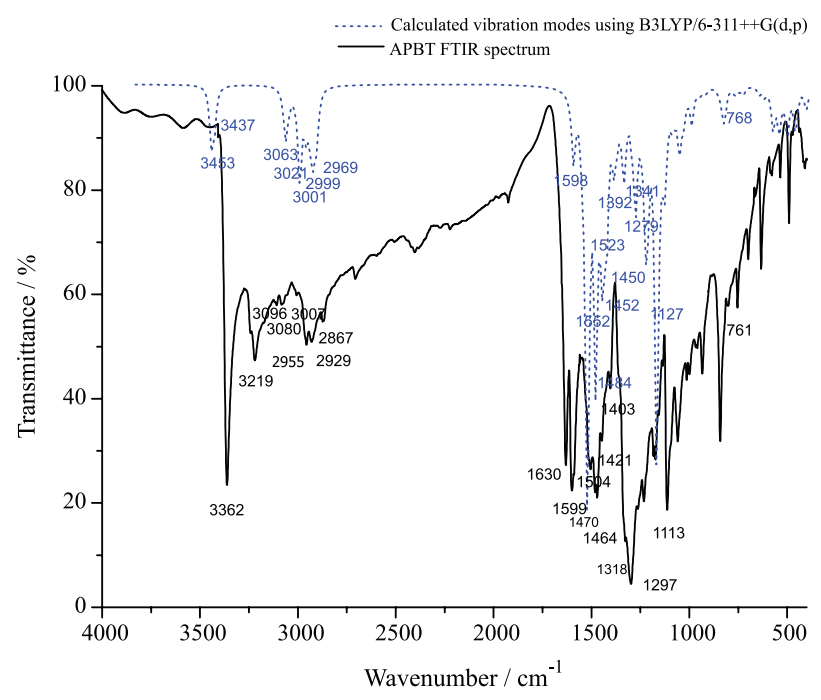

Figure 2. Experimental and calculated IR spectra of APBT using B3LYP/ 6-311++G(d,p).

\section{$\mathrm{C}-\mathrm{H}_{\text {pyrazine }}$ vibrations}

$\mathrm{C}-\mathrm{H}$ stretching for the pyrazine ring occurred at a higher wavenumber compared to the $\mathrm{C}-\mathrm{H}$ stretching for $\mathrm{CH}_{2}$ or $\mathrm{CH}_{3}$ in this compound. The theoretical calculated $\mathrm{C}-\mathrm{H}$ stretching vibrations for the pyrazine ring were found at 3090 and $3073 \mathrm{~cm}^{-1} ;{ }^{20}$ these two peaks were assigned in the experimental spectrum at 3096 and $3080 \mathrm{~cm}^{-1} .^{22}$

\section{$\mathrm{CH}_{2}$ and $\mathrm{CH}_{3}$ vibrations}

The observations show that $\mathrm{CH}_{2}$ stretching peaks were found at 2935 and $2911 \mathrm{~cm}^{-1} .23$ The experimental only showed the two peaks at 2929 and $2867 \mathrm{~cm}^{-1} .{ }^{21}$ The 
Table 2. Selected experimental and theoretical vibrational frequencies of APBT with B3LYP6-311++G(d,p)

\begin{tabular}{|c|c|c|c|c|}
\hline \multirow{2}{*}{$\begin{array}{l}\text { Experimental } \\
\text { frequency } / \mathrm{cm}^{-1}\end{array}$} & \multicolumn{2}{|c|}{ Calculated frequency $/ \mathrm{cm}^{-1}$} & \multirow{2}{*}{ Intensity } & \multirow{2}{*}{ Vibrational assignment (PED $\geq 10 / \%)$} \\
\hline & Unscaled & Scaled & & \\
\hline 3363 & 3587 & 3453 & 53.59 & $v[(\mathrm{~N} 20 \mathrm{H} 21)](99)$ \\
\hline 3219 & 3571 & 3438 & 35.78 & $v[(\mathrm{~N} 16 \mathrm{H} 17)](99)$ \\
\hline 3096 & 3210 & 3090 & 4.30 & $v[(\mathrm{C} 5 \mathrm{H} 9)](96)$ \\
\hline 3080 & 3192 & 3073 & 48.20 & $v[(\mathrm{C} 1 \mathrm{H} 7)](93)$ \\
\hline 2929 & 3049 & 2935 & 40.63 & $v[(\mathrm{C} 22 \mathrm{H} 23)](85)$ \\
\hline 2867 & 3024 & 2911 & 25.51 & $v[(\mathrm{C} 28 \mathrm{H} 29)](13)$ \\
\hline 1630 & 1660 & 1598 & 63.95 & $v[(\mathrm{~N} 15 \mathrm{C} 11)](63)$ \\
\hline 1599 & 1612 & 1552 & 29.64 & $v[(\mathrm{~N} 15 \mathrm{C} 10)](52)+\delta[(\mathrm{H} 8 \mathrm{C} 2 \mathrm{~N} 3)](21)$ \\
\hline 1504 & 1582 & 1523 & 139.60 & $v[(\mathrm{~N} 6 \mathrm{C} 5)](69)$ \\
\hline 1470 & 1541 & 1484 & 264.09 & $\delta[(\mathrm{H} 17 \mathrm{~N} 16 \mathrm{~N} 1) 5](53)$ \\
\hline 1464 & 1522 & 1465 & 3.67 & $\delta[(\mathrm{H} 32 \mathrm{C} 31 \mathrm{H} 33)](68)+\tau[(\mathrm{H} 29 \mathrm{C} 28 \mathrm{C} 31 \mathrm{H} 33)](10)$ \\
\hline 1176 & 1217 & 1172 & 359.38 & $v[(\mathrm{~N} 16 \mathrm{C} 18)](41)+\tau[(\mathrm{H} 29 \mathrm{C} 28 \mathrm{C} 25 \mathrm{C} 22)](10)$ \\
\hline 1113 & 1180 & 1136 & 33.01 & $v[(\mathrm{~N} 15 \mathrm{~N} 160)](17)+\tau[(\mathrm{H} 29 \mathrm{C} 28 \mathrm{C} 25 \mathrm{C} 22)](26)$ \\
\hline 1104 & 1171 & 1127 & 60.45 & $v[(\mathrm{~N} 15 \mathrm{~N} 16)](38)$ \\
\hline 1064 & 1096 & 1055 & 55.20 & $v[(\mathrm{C} 22 \mathrm{C} 25)](30)+v[(\mathrm{~S} 19 \mathrm{C} 18)](30)+\tau[(\mathrm{H} 33 \mathrm{C} 31 \mathrm{C} 28 \mathrm{C} 25)](10)$ \\
\hline 1008 & 1055 & 1016 & 0.26 & $\gamma[(\mathrm{H} 13 \mathrm{C} 11 \mathrm{H} 14)](14)+\tau[(\mathrm{C} 11 \mathrm{H} 12 \mathrm{C} 10 \mathrm{H} 13)](72)$ \\
\hline 800 & 856 & 824 & 29.52 & $v[(\mathrm{~S} 19 \mathrm{C} 18)](25)+\delta[(\mathrm{C} 1 \mathrm{C} 2 \mathrm{~N} 3)](14)$ \\
\hline 641 & 672 & 647 & 7.31 & $v[(\mathrm{~S} 19 \mathrm{C} 18)](11)+\delta[(\mathrm{C} 11 \mathrm{C} 10 \mathrm{~N} 15)](46)$ \\
\hline 417 & 423 & 407 & 12.83 & $\tau[(\mathrm{C} 2 \mathrm{C} 1 \mathrm{~N} 6 \mathrm{C} 5)](84)$ \\
\hline
\end{tabular}

PED: potential energy distribution; $v$ : stretching; $\delta$ : in-plane bending; $\gamma$ : out-of-plane bending; $\tau$ : torsion. ${ }^{21}$

Table 3. Calculated HOMO and LUMO energies, energy gap, electronegativity, chemical potential, global hardness, global softness, global electrophilicity index and additional electronic charge for reactants A and B, and the title compound using B3LYP/6-311++G(d,p)

\begin{tabular}{lcccccccccc}
\hline & $\mathrm{E}_{\mathrm{H}} / \mathrm{eV}$ & $\mathrm{E}_{\mathrm{L}} / \mathrm{eV}$ & $\mathrm{E}_{\mathrm{H}}-\mathrm{E}_{\mathrm{L}} / \mathrm{eV}$ & $\mu / \mathrm{eV}$ & $\chi / \mathrm{eV}$ & $\eta / \mathrm{eV}$ & $\mathrm{s} / \mathrm{eV}^{-1}$ & $\omega / \mathrm{eV}$ & $-\mu / \eta$ & $\mathrm{ECT}$ \\
\hline Reactant A & -7.0314 & -5.5378 & -1.4936 & -6.2846 & 6.2846 & 0.7468 & 0.6695 & 26.4436 & 8.4154 & - \\
Reactant B & -9.7863 & -4.6483 & -5.138 & -7.2173 & 7.2173 & 2.5690 & 0.1946 & 10.1381 & 2.8094 & 5.6056 \\
APBT & -7.5514 & -5.4371 & -2.1143 & -6.4943 & 6.4943 & 1.0572 & 0.4729 & 19.947 & - & - \\
\hline
\end{tabular}

$\mathrm{E}_{\mathrm{H}}$ and $\mathrm{E}_{\mathrm{L}}$ : calculated HOMO and LUMO energies, respectively; $\mu$ : chemical potential; $\chi$ : electronegativity; $\eta$ : global hardness; s: global softness; $\omega$ : global electrophilicity index; $-\mu / \eta$ : additional electronic charge; ECT: electrophilicity-based charge transfer; APBT: N(4)butylthiosemicarbazone.

calculated in-plane and out-of-plane bending vibrations of methyl group were assigned at 1465 and $1016 \mathrm{~cm}^{-1}{ }^{23,24}$ The experimental bending vibrations for methyl group were found at $1464^{25}$ and $1008 \mathrm{~cm}^{-1} .{ }^{26}$

\section{$\mathrm{C}=\mathrm{N}$ and $\mathrm{C}-\mathrm{N}$ vibrations}

The highest wavenumber of $\mathrm{C}=\mathrm{N}$ was observed in the recorded FTIR spectrum at $1630 \mathrm{~cm}^{-1}$, assigned to the $\mathrm{C}=\mathrm{N}$ stretching vibration in the thiosemicarbazone moiety..$^{27,28}$ The calculated value was $1598 \mathrm{~cm}^{-1} .{ }^{20}$ The ring $\mathrm{C}=\mathrm{N}$ stretching vibrations in the pyrazine ring were observed in the region of $1599-1504 \mathrm{~cm}^{-1},{ }^{16,29}$ these wavenumbers were found at 1552,1529 and $1523 \mathrm{~cm}^{-1}$ in the calculation computed by B3LYP/6-311++G(d,p). ${ }^{30}$ The calculations also showed that the assymmetric and symmetric stretching vibration of N16-C18-N20 occured at 1529 and $1172 \mathrm{~cm}^{-1}$, respectively. The C18-N16 stretching mode corresponding to experimental value was found at $1176 \mathrm{~cm}^{-1}$. 30,31 The details of vibrational frequencies can be seen in Table S5 (SI section).

\section{$\mathrm{C}=\mathrm{S}$ vibrations}

The calculated wavenumbers of $\mathrm{C}=\mathrm{S}$ stretching were 1055,824 and $647 \mathrm{~cm}^{-1},{ }^{20,23}$ with PED contributions of 30,25 and $11 \%$, respectively. The experimental spectrum showed bands for $\mathrm{C}=\mathrm{S}$ stretching at 1064, 800 and $641 \mathrm{~cm}^{-1} .32-34$ The absent band at $2500 \mathrm{~cm}^{-1}$ in the recorded and calculated spectra indicates that in both the solid state and as a gas/in a vacuum, the ligand remains as a thione tautomer.

\section{$\mathrm{N}-\mathrm{N}$ vibrations}

The calculated $\mathrm{N}-\mathrm{N}$ stretching vibrations with PED contributions of 17 and $38 \%$ were found at 1136 and $1127 \mathrm{~cm}^{-1} \cdot 23,34$ In the recorded FTIR spectrum, these were observed at 1113 and $1104 \mathrm{~cm}^{-1}$, as reported in the 
literature and assigned to $\mathrm{N}-\mathrm{N}$ stretching vibrations. ${ }^{35}$ The calculated in-plane bending vibration for $\mathrm{H}-\mathrm{N}-\mathrm{N}$ was found at $1484 \mathrm{~cm}^{-1}$ and the experimental showed peak at $1470 \mathrm{~cm}^{-1} .^{21}$

\section{Global reactivity descriptors}

Global reactivity descriptors were evaluated to understand the relationship between structure, stability and global chemical reactivity. The energy levels of HOMO and LUMO play specific roles for all parameters. HOMO is the orbital that acts as an electron donor while LUMO is the orbital that acts as the electron acceptor. The 3D plots of selected molecular orbitals and the energy gap of each electronic transition are shown in Figure 3. As seen from Figure 3, the HOMO orbital is mainly localized over S19 while LUMO orbital is mainly delocalized over pyrazine ring. The Figure represents $n-\pi *$ electronic transition of the title compound. The highest energy gap was found at

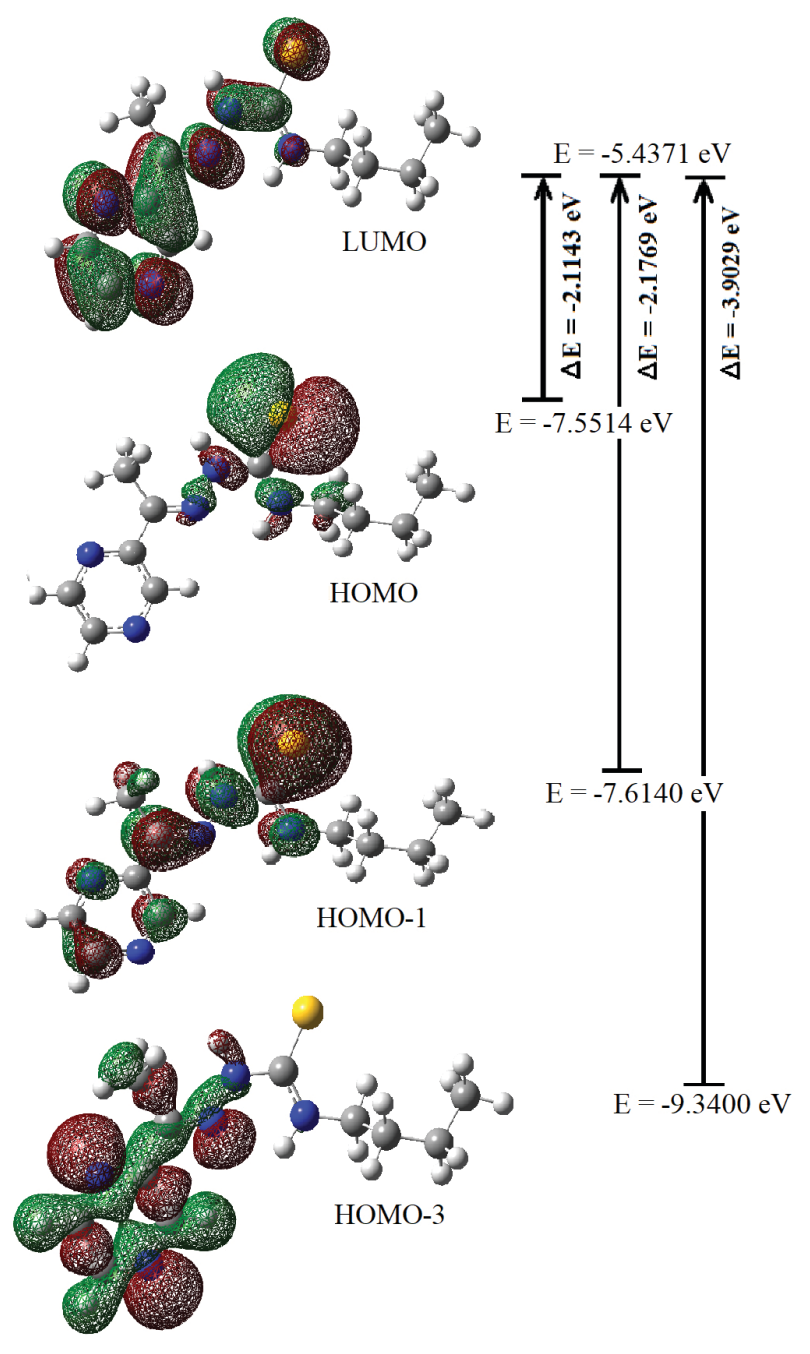

Figure 3. Energies of the molecular orbitals.
$-2.1143 \mathrm{eV}$, which indicated the most stable electronic transition of the title compound.

The global chemical reactivity parameters, such as chemical potential $(\mu)$, electronegativity $(\chi)$, chemical hardness $(\eta)$, global softness (s), global electrophilicity index $(\omega)^{36-40}$ and electrophilicity-based charge transfer $(\mathrm{ECT})^{41}$ of reactant A, reactant B and APBT, were evaluated from the HOMO and LUMO energy levels using the following equations. The results are listed in Table 3.

$\mu=1 / 2(\mathrm{I}+\mathrm{A})=-\chi$
$\eta=1 / 2(\mathrm{~A}-\mathrm{I})$
$\mathrm{s}=1 / 2 \eta$

$\omega=\mu^{2} / 2 \eta$

$\mathrm{ECT}=\left(\Delta \mathrm{N}_{\max }\right) \mathrm{A}-\left(\Delta \mathrm{N}_{\max }\right) \mathrm{B}$, where $\left(\Delta \mathrm{N}_{\max }\right)=-\mu / \eta(5)$

Figure S3 (SI section) shows the optimized geometries of the reactants and product involved in the chemical reaction calculated at the B3LYP/6-311++G(d,p) level. The calculated energy gap of frontier molecular orbital of reactant $\mathrm{A}$ is $-1.4936 \mathrm{eV}$, while reactant $\mathrm{B}$ is $-5.138 \mathrm{eV}$, respectively. The value indicates that reactant $\mathrm{B}$ is more reactive than reactant $A$. The hard molecule has high value of hardness (reactant B) contributed from the large energy band gap, while soft molecule has high value of softness (reactant A) contributed from small energy gap. ${ }^{38}$ The calculated data also show that reactant $A$ has a high value of chemical potential $(-6.2846 \mathrm{eV})$ and a high electrophilicity index $(26.4436 \mathrm{eV})$, so it acts as the electrophile, while the high value of electronegativity $(7.2173 \mathrm{eV})$ shows that reactant $\mathrm{B}$ acts as the nucleophile. The ECT value of 5.6056 $(\mathrm{ECT}>0)$ also shows that charge flow from reactant $\mathrm{B}$ to reactant $\mathrm{A}$ indicates that reactant $\mathrm{B}$ acts as nucleophile while reactant $\mathrm{A}$ acts as electrophile.

\section{Fukui function}

The Fukui function is a method in quantum chemistry used by chemists to recognize and provide information on which atom in a molecule has a greater tendency to either lose or accept an electron. The function also defines which atom is more prone to nucleophilic or electrophilic attack, respectively. The Fukui function is a local reactivity descriptor that indicates the preferred regions where a chemical species will change its density when the number of electrons is modified. It is defined as ${ }^{42}$

$\mathrm{f}(\mathrm{r})=\frac{\delta \rho(\mathrm{r})}{\partial \mathrm{N}} \mathrm{r}$

where $\rho(r)$ is the electronic density, $N$ is the number of electrons and $\mathrm{r}$ is the external potential exerted by the 
nucleus. $\left(\mathrm{f}_{\mathrm{k}}{ }^{+}, \mathrm{f}_{\mathrm{k}}^{-}, \mathrm{f}_{\mathrm{k}}{ }^{0}\right)$ were calculated using the following equations:

$\mathrm{f}_{\mathrm{k}}{ }^{+}=[\mathrm{q}(\mathrm{N}+1)-\mathrm{q}(\mathrm{N})]$ for nucleophilic attack

$\mathrm{f}_{\mathrm{k}}^{-}=[\mathrm{q}(\mathrm{N})-\mathrm{q}(\mathrm{N}-1)]$ for electrophilic attack

$\mathrm{f}_{\mathrm{k}}{ }^{0}=1 / 2[\mathrm{q}(\mathrm{N}+1)-\mathrm{q}(\mathrm{N}-1)]$ for radical attack

where $\mathrm{N}, \mathrm{N}-1, \mathrm{~N}+1$ are the total electrons present in the neutral, cationic and anionic states of the molecule, respectively. The local softness $\left(\mathrm{s}_{\mathrm{k}}{ }^{+}, \mathrm{s}_{\mathrm{k}}{ }^{-}, \mathrm{s}_{\mathrm{k}}{ }^{0}\right)$ and local electrophilicity indices $\left(\omega_{\mathrm{k}}{ }^{+}, \omega_{\mathrm{k}}{ }^{-}, \omega_{\mathrm{k}}{ }^{0}\right)$ were also evaluated to determine the selectivity of active sites in the molecule. The calculations of the selected reactivity sites of the reactants $\mathrm{A}$ and $\mathrm{B}$ are given in Table 4. The maximum value of the local descriptor prone to nucleophilic attack $\left(\mathrm{f}_{\mathrm{k}}{ }^{+}, \mathrm{s}_{\mathrm{k}}{ }^{+}, \omega_{\mathrm{k}}{ }^{+}\right)$ was found for the $\mathrm{C} 18$ atom (reactant $\mathrm{A}$ ) which had values of $(0.1972,0.0736,5.2149)$, while the N14 atom (reactant B) had the maximum $\left(\mathrm{f}_{\mathrm{k}}^{-}, \mathrm{s}_{\mathrm{k}}{ }^{-}, \omega_{\mathrm{k}}{ }^{-}\right)$values of $(0.6822,1.4811$, 2.3286) and is prone to electrophilic attack.

\section{Atomic charge analysis}

The charge distribution of the molecule was calculated on the basis of the Mulliken method using B3LYP/6$311++\mathrm{G}(\mathrm{d}, \mathrm{p})$ level calculations. This calculation depicts the charges of every atom in the molecule. Mulliken population analysis computes charges by dividing the orbital overlap evenly between the two atoms involved. ${ }^{43}$ As shown in Figure 4, the atoms which exhibit a negative charge are N3, N6, C11, N15, N16, S19, N20, C22, C25, $\mathrm{C} 28$ and $\mathrm{C} 31$, while $\mathrm{C} 1, \mathrm{C} 2, \mathrm{C} 4, \mathrm{C} 5, \mathrm{C} 10$, and $\mathrm{C} 18$ exhibit positive charges. All hydrogen atoms possess positive charges. The maximum negatively charged atom (N20) is in the neighborhood of the maximum positively charged atom (C18).

\section{Molecular electrostatic potential}

The molecular electrostatic potentials (MEP) of the reactants and product in 3D plots are illustrated in Figure 5. Molecular electrostatic potential is widely used as a reactivity map displaying the regions for electrophilic and nucleophilic attack. ${ }^{44-46} \mathrm{As}$ can be seen, the region of the $\mathrm{C} 18$ atom of reactant $\mathrm{A}$ is in green, indicating that it experiences the strongest repulsion, while the region surrounding the $\mathrm{N} 14$ atom is in red, and therefore experiences the strongest attraction in the reaction mechanism. The region of N14 in reactant $\mathrm{B}$ acts as the nucleophile and has the strongest attraction for the region of $\mathrm{C} 18$ in reactant $\mathrm{A}$, which acts as the electrophile to form the title compound.

Table 4. Selected electrophilic reactivity descriptors $\left(\mathrm{f}_{\mathrm{k}}{ }^{+}, \mathrm{s}_{\mathrm{k}}{ }^{+}, \omega_{\mathrm{k}}{ }^{+}\right)$for reactant A and nucleophilic reactivity descriptors $\left(\mathrm{f}_{\mathrm{k}}^{-}, \mathrm{s}_{\mathrm{k}}{ }^{-}, \omega_{\mathrm{k}}{ }^{-}\right)$for reactant $\mathrm{B}$ using Mulliken charge analyses

\begin{tabular}{|c|c|c|c|c|c|c|c|}
\hline \multicolumn{4}{|c|}{ Reactant A } & \multicolumn{4}{|c|}{ Reactant B } \\
\hline Site & $\mathrm{f}_{\mathrm{k}}^{+}$ & $\mathrm{s}_{\mathrm{k}}^{+}$ & $\omega_{\mathrm{k}}^{+}$ & Site & $\mathrm{f}_{\mathrm{k}}^{-}$ & $\mathrm{s}_{\mathrm{k}}^{-}$ & $\omega_{\mathrm{k}}^{-}$ \\
\hline $\mathrm{C} 10$ & 0.1875 & 0.07 & 4.9594 & N14 & 0.6822 & 1.4811 & 2.3286 \\
\hline $\mathrm{C} 18$ & 0.1972 & 0.0736 & 5.2149 & & & & \\
\hline
\end{tabular}

$\mathrm{f}_{\mathrm{k}}^{+}, \mathrm{s}_{\mathrm{k}}{ }^{+}, \omega_{\mathrm{k}}^{+}$: Fukui function, softness and electrophilicity indices, respectively, for electrophilic reactivity; $\mathrm{f}_{\mathrm{k}}^{-}, \mathrm{s}_{\mathrm{k}}^{-}, \omega_{\mathrm{k}}^{-}$: Fukui function, softness and electrophilicity indices, respectively, for nucleophilic reactivity.

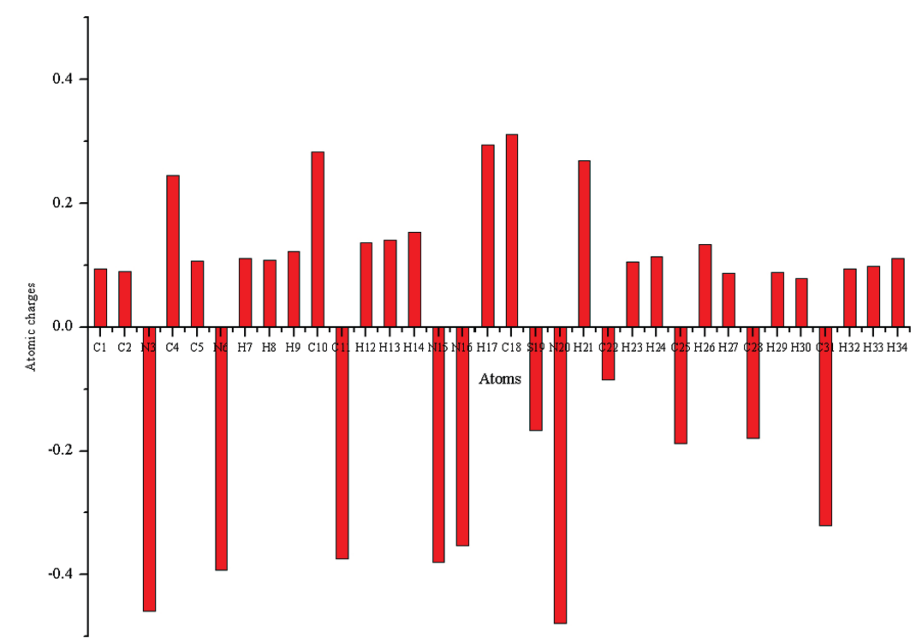

Figure 4. Bar diagram representing the charge distribution of APBT. 


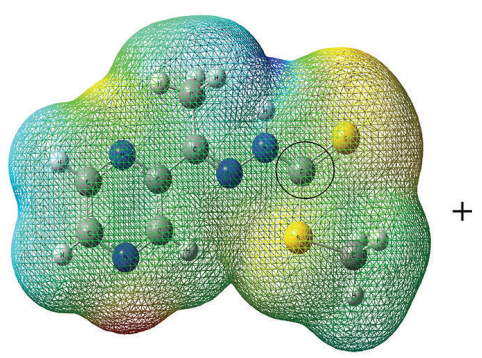

Reactant A

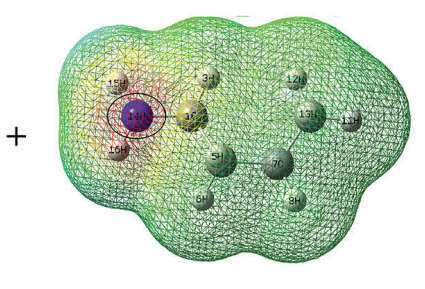

Reactant B

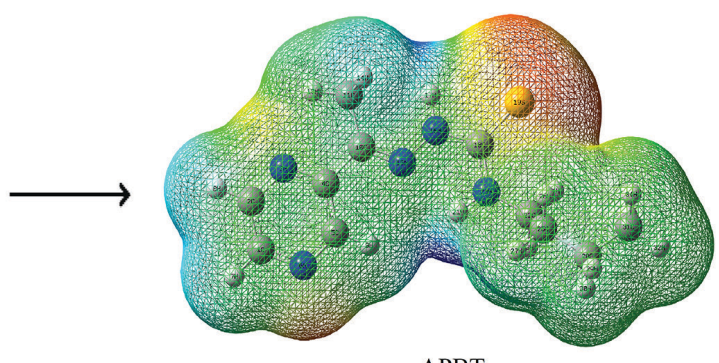

APBT

Figure 5. Molecular electrostatic potential for the reactants and the title compound.

\section{Molecular docking}

The CDK2 complex data file was obtained from the Protein Data Bank. CDK as a protein receptor was prepared by removing the waters and cocrystallized ligand using Discovery Studio Visualizer. ${ }^{47}$ Calculation of the interaction between the optimized title compound and the protein receptor CDK2 within the grid box size of $30 \times 30 \times 30 \AA^{3}$ showed the formation of a stable complex with value $-6.4 \mathrm{kcal} \mathrm{mol}^{-1}$ (Table 5). As shown in Figure 6, the interaction of amino acid ASP 145 forms a $\pi$ anion ( $3.58 \AA$ ) with the pyrazine ring, GLN 131 forms a hydrogen bond $(2.07 \AA)$ with $\mathrm{N}(16) \mathrm{H}$, ASN 132 forms a carbon hydrogen bond (3.59 $)$ with C(5)pyrazine and PHE 80 forms a $\pi-\sigma(3.56 \AA)$ interaction with $\mathrm{C}(31)$. The preliminary results suggest
Table 5. The binding affinity values of different poses of the title compound

\begin{tabular}{lccc}
\hline \multirow{2}{*}{ Mode } & $\begin{array}{c}\text { Affinity / } \\
\left(\text { kcal mol }^{-1}\right)\end{array}$ & \multicolumn{2}{c}{ Distance from the best mode / $\AA$} \\
\cline { 2 - 4 } 1 & -6.4 & 0.000 & RMSD 1b \\
2 & -6.3 & 4.334 & RMSD ub \\
\hline 3 & -6.2 & 2.099 & 7.190 \\
4 & -6.1 & 3.087 & 3.182 \\
5 & -6.1 & 2.830 & 6.067 \\
6 & -5.9 & 4.667 & 6.546 \\
7 & -5.9 & 3.837 & 7.154 \\
8 & -5.8 & 1.939 & 6.408 \\
9 & -5.8 & 3.789 & 2.908 \\
\hline
\end{tabular}

RMSD: root mean square deviation; lb: lower bound; ub: upper bound.

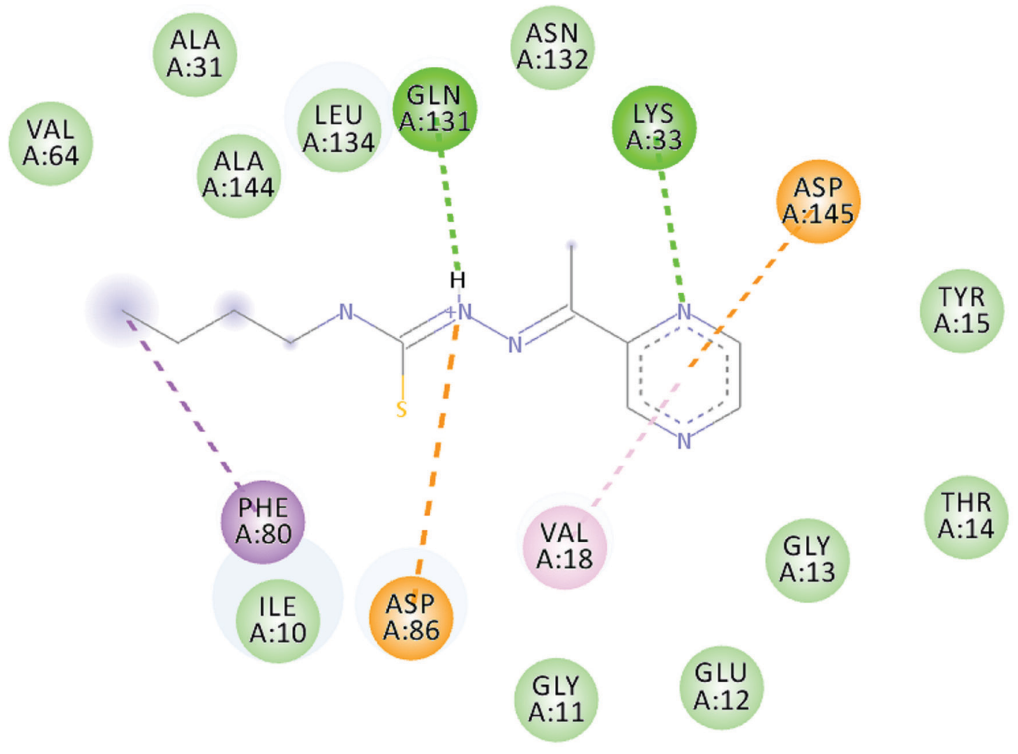

Interactions
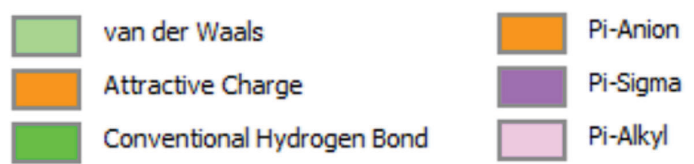

Figure 6. Two-dimensional interaction of APBT with amino acid residues shown as balls colored by the type of interaction. 
that the title compound has potential as an inhibitor of the CDK2 protein.

\section{Conclusions}

A thiosemicarbazone ligand (APBT) was synthesized and characterized using elemental analysis, NMR and FTIR spectroscopies. The calculation using B3LYP/6-311++G(d,p) was used to compute the chemical properties of the new ligand. The optimized geometric parameters and vibrational frequencies were compared with the experimental data. The small energy gap frontier molecular orbital of reactant B indicates that the molecule is more reactive than reactant $\mathrm{A}$. Reactant A has high value of softness $\left(0.6695 \mathrm{eV}^{-1}\right)$, chemical potential $(-6.2846 \mathrm{eV})$ and electrophilicity index $(26.4433 \mathrm{eV})$, and acts as electron acceptor or electrophile, while reactant $\mathrm{B}$, which has high value of hardness $(2.569 \mathrm{eV})$ and electronegativity $(7.2173 \mathrm{eV})$, acts as electron donor or nucleophile, forming the title compound. The specific sites within the molecule that acted as the electrophile and nucleophile were identified using the Fukui function. The result shows atom $\mathrm{C}(18)$ from reactant $\mathrm{A}$ is prone to nucleophilic attack, while $\mathrm{N}(14)$ from reactant $\mathrm{B}$ is prone to electrophilic attack. The 3D MEP plots also helped to show the regions of the reaction active sites in reactants $\mathrm{A}$ and $\mathrm{B}$. These results will be used to design and synthesize new potential inhibitors for the CDK2 protein, which is attractive for anticancer treatment.

\section{Experimental}

The melting point was obtained on an Electrothermal 9300 digital melting point apparatus. Elemental analysis of APBT was performed using CHN-S Fison EA 1108 and IR spectra was recorded using $\mathrm{KBr}$ on a Perkin Elmer FTIR GX spectrometer. The ${ }^{1} \mathrm{H}$ and ${ }^{13} \mathrm{C}$ NMR spectra were recorded in parts per million (ppm) using JEOL ECP $400 \mathrm{MHz}$ spectrometer in DMSO- $d_{6}$ and were referenced to the residual solvent peak.

Procedure for acetylpyrazine N(4)butylthiosemicarbazone (APBT)

All the chemicals used were of analytical grade. Methyl 3-[1-(2-pyrazyl)ethylenediene]hydrazinecarbodithiote $(0.68 \mathrm{~g}, 3 \mathrm{mmol})$ was dissolved in hot butanol $(300 \mathrm{~mL})$, and butylamine $(0.26 \mathrm{~g}, 3 \mathrm{mmol})$ was added, then the mixture was refluxed for $24 \mathrm{~h} .{ }^{48} \mathrm{~A}$ yellow precipitate formed after the solution was evaporated for 14 days. The product was filtered off and dried in a desiccator. The product yield was $59 \%$ and the melting point was $189-191^{\circ} \mathrm{C}$. The elemental analysis showed C 53.20, H 6.73, N 28.40, S 11.67\%, whereas the calculated formula was $\mathrm{C}_{11} \mathrm{H}_{17} \mathrm{~N}_{5} \mathrm{~S}$; C 52.56, $\mathrm{H} 6.82$, N 27.86, S 12.76\%; IR (KBr) v / cm $\mathrm{cm}^{-1} 3363,3219$, $1630,1064,800$ and 641, 1113, 1104, 1599, 1504, 3004, 2955, 2929, 2867; ${ }^{1} \mathrm{H}$ NMR (400 MHz, DMSO- $d_{6}$ ) $\delta 10.13$ (s, 1H, NH), $9.79(\mathrm{~s}, 1 \mathrm{H}, \mathrm{NH}), 2.50(\mathrm{~s}, 3 \mathrm{H}, \mathrm{CH}), 9.65$ $\left(1 \mathrm{H}, \mathrm{CH}_{\text {pyrazine }}\right), 8.62,\left(\mathrm{~d}, 2 \mathrm{H}, \mathrm{CH}_{\text {pyrazine }}\right), 0.54,1.39,1.48$, $1.70\left(9 \mathrm{H}, \mathrm{C}-\mathrm{H}_{\text {aliphatic }}\right) ;{ }^{13} \mathrm{C}$ NMR $\left(400 \mathrm{MHz}\right.$, DMSO- $\left.d_{6}\right)$ $\delta 144.77,143.95,150.70,150.99,145.88,13.11,170.38$, $30.99,19.88,18.35,12.34$.

\section{Computational methods}

In this study, the DFT calculations were carried out using the GAUSSIAN 09 program. ${ }^{49}$ DFT/B3LYP at the 6-311++G(d,p) basis set level was adopted to optimize geometrical parameters in gas phase and the most stable conformation (lowest total energy) was taken from the final optimization step calculation for all theoretical considerations. The 6-311++G (d,p) with 'd' and 'p' polarization function on heavy atoms and hydrogen atoms, respectively, was chosen to get a better description of polar bonds of the title compound. The computed harmonic frequencies were scaled by $0.9627^{50}$ (B3LYP) to improve the agreement between the predicted and observed frequencies. The characterization of vibration frequencies was clarified by means of the PED using vibrational energy distribution analysis (VEDA) 4 program..$^{51}$ The GaussView 5.0 program ${ }^{52}$ was used to construct the optimized molecular geometry, HOMO and LUMO electron distributions and the HOMO-LUMO energy gap. The ADT 4.2 software $^{53,54}$ was used to calculate the binding affinity between CDK2 macromolecule and the title compound, and the ligand-substate interaction was analyzed using Discovery Studio Visualizer 2016. ${ }^{47}$

\section{Supplementary Information}

Supplementary information is available free of charge at http://jbcs.sbq.org.br as PDF file.

\section{Acknowledgments}

The authors are thankful to International Islamic University Malaysia and the Ministry of Higher Education, Malaysia, for supporting this research through grant FRGS15-205-0446.

\section{References}

1. Jouad, E. M.; Allain, M.; Khan, M. A.; Bouet, G. M.; Polyhedron 2005, 24, 327. 
2. Uesugi, K.; Sik, L. J.; Nishioka, H.; Kumagai, T.; Nagahiro, T.; Microchem. J. 1994, 50, 88.

3. Tian, Y.; Duan, C.; Zhao, C.; You, X.; Inorg. Chem. 1997, 36, 1247.

4. West, D. G.; Bain, G. A.; Polyhedron 1996, 15, 665.

5. El-Ayaan, U.; Youssef, M. M.; Youssef, S.; Al-Sihry.; J. Mol. Struct. 2009, 936, 213.

6. Valdez-Martinez, J.; Toscano, R. A.; Ramirez-Ortiz, J.; Polyhedron 1995, 14, 579.

7. Khan, S. A.; Kumar, P.; Joshi, R.; Iqbal, P. F.; Saleem, K.; Eur. J. Med. Chem. 2008, 43, 2029.

8. Degola, F.; Morcia, C.; Bisceglie, F.; Mussi, F.; Tumino, G.; Ghizzoni, R.; Pelosi, G.; Terzi, V.; Buschini, A.; Restivo, F. M.; Lodi, T.; Int. J. Food Microbiol. 2015, 200, 104.

9. Hu, W.-X.; Zhou, W.; Xia, C.-N.; Wen, X.; Bioorg. Med. Chem. Lett. 2006, 16, 2213.

10. Hu, S.; Danilov, A. V.; Godek, K.; Orr, B.; Tafe, L. J.; RodriguezCanales, J.; Behrens, C.; Mino, B.; Moran, C. A.; Memoli, V. A.; Mustachio, L. M.; Galimberti, F.; Ravi, S.; DeCastro, A.; Lu, Y.; Sekula, D.; Andrew, A. S.; Wistuba, I. I.; Freemantle, S.; Compton, D. A.; Dmitrovsky, E.; Cancer Res. 2015, 75, 2029.

11. Sholl, D. S.; Steckel, J. A.; Density Functional Theory, A Practical Introduction, $1^{\text {st }}$ ed.; John Wiley and Sons: Hoboken, 2009.

12. Normaya, E.; Farina, Y.; Halim, S. N. A.; Tienkink, E. R. T.; Acta Crystallogr. 2011, E67, o943.

13. Kaminsky, W.; Jasinski, J. P.; Woundenberg, R.; Goldberg, K. I.; West, D. G.; J. Mol. Struct. 2002, 608, 135.

14. Li, M. X.; Chen, C. L.; Ling, C. S.; Zhou, J.; Ji, B. S.; Wu, Y. J.; Niu, J. Y.; Bioorg. Med. Chem. Lett. 2009, 19, 2704.

15. Casas, J. S.; Castellano, E. E.; Ellena, J.; Garcia-Tasende, M. S.; Sanchez, A.; Sordo, J.; Touseda, A.; Polyhedron 2009, 28, 1029.

16. Rajamani, T.; Muthu, S.; Spectrochim. Acta, Part A 2013, 115, 654.

17. Ferrari, M. B.; Pelizzi, C.; Pelosi, G.; Rodriguez-Arguelles, M. C.; Polyhedron 2002, 21, 2593.

18. Leovac, V. M.; Bogdanovic, G. A.; Jovanovic, L. S.; Joksovic, L.; Markovic, V.; Joksvic, M. D.; Dencic, S. M.; Isakovic, A.; Markovic, I.; Heinemann, F. H.; Trifunovic, S.; Dalovic, I.; J. Inorg. Biochem. 2011, 105, 1413.

19. Singh, R. N.; Kumar, A.; Tiwari, R. K.; Rawat, P.; Verma, D.; Baboo, V.; J. Mol. Struct. 2012, 1016, 97.

20. Li, X.-H.; Mei, Z.; Zhang, X.-Z.; Spectrochim. Acta, Part A 2014, 118, 543.

21. Sert, Y.; Miroslaw, B.; Cirak, C.; Dogan, H.; Szulczyk, D.; Struga, M.; Spectrochim. Acta, Part A 2014, 128, 91.

22. Coates, J.; Mayers, R. A.; Interpretation of Infrared Spectra, A Practical Approach; John Wiley \& Sons: Chichester, 2000, p. 10815.
23. Anoop, M. R.; Binil, P. S.; Suma, S.; Sudarsanakumar, M. R.; Mary, S.; Varghese, H. T.; Panicker, C. Y.; J. Mol. Struct. 2010, 969, 48.

24. Singh, R. N.; Kumar, A.; Tiwari, R. K.; Rawat, P.; Spectrochim. Acta, Part A 2013, 112, 182.

25. Tzeng, W. B.; Narayanan, K.; Lin, J. L.; Tung, C. C.; Spectrochim. Acta, Part A 1999, 55, 153.

26. Varsanyi, G.; Assignment for Vibrational Spectra of Seven Hundred Benzene Derivatives, vol. 1 and 2; Academic Kiado: Budapest, 1973.

27. Alomar, K.; Khan, M. A.; Allain, M.; Bouet, G.; Polyhedron 2009, 28, 1273.

28. Zhang, L. Z.; An, G. Y.; Yang, M.; Li, M. X.; Zhu, X. F.; Inorg. Chem. Commun. 2012, 20, 37.

29. Sundaraganesan, N.; Kumar, K. S.; Meganathan, C.; Joshua, B. D.; Spectrochim. Acta, Part A 2006, 65, 1186.

30. Ranjith, P. K.; Al-Abdullah, E. S.; Al-Omary, F. M. A.; ElEmam, A. A.; Anto, P. L.; Sheena, M. Y.; Armakovic, S.; Armakovic, S. J.; Zitco, J.; Dolezal, M.; Alsenoy, C. V.; J. Mol. Struct. 2017, 1136, 14

31. Renuga, S.; Karthikesan, M.; Muthu, S.; Spectrochim. Acta, Part A 2014, 127, 439.

32. Pavia, D. L.; Lampman, G. M.; Kriz, G. S.; Vyvyan, J. R.; Introduction to Spectroscopy, $4^{\text {th }}$ ed.; Brooks/Cole: Belmont, 2010.

33. Perez-Rebolledo, A.; Mendes, I. C.; Speziali, N.; Bertani, P.; Resende, J. M.; Alcantara, A. F. D. C.; Beraldo, H.; Polyhedron 2007, 26, 1449.

34. Thanikachalam, V.; Periyanayagasamy, V.; Jayabharathi, J.; Manikandan, G.; Saleem, H.; Subashchandrabose, S.; Erdogdu, Y.; Spectrochim. Acta, Part A 2012, 87, 86.

35. Joseph, M.; Kuriakose, M.; Kurup, M. R. P.; Suresh, E.; Kishore, A.; Bhat, S. G.; Polyhedron 2014, 25, 61.

36. Chattaraj, P. K.; Giri, S. G.; J. Phys. Chem. A 2007, 111, 1116.

37. Geerlings, P. G.; De Proft, F.; Langenaeker, W.; Chem. Rev. 2003, 103, 1793.

38. Parr, R. G.; Pearson, R. G.; J. Am. Chem. Soc. 1983, 105, 7512.

39. Parr, R. G.; Szentpaly, L. V.; Liu, S.; J. Am. Chem. Soc. 1999, 121, 1922.

40. Pearson, R. G.; J. Org. Chem. 1989, 54, 1423.

41. Padmanabhan, J.; Partasarathi, R.; Subramaniaan, V.; Chattaraj, P. K.; J. Phys. Chem. A 2007, 111, 1358.

42. Parr, R. G.; Yang, W.; Density-Functional Theory of Atoms and Molecules, $1^{\text {st }}$ ed.; Oxford University Press: New York, 1989.

43. Sidir, I.; Sidir, Y. G.; Kumalar, M.; Tasal, E.; J. Mol. Struct. 2010, 964, 134.

44. Luque, F. J.; Lopez, J. M.; Orozco, M.; Theor. Chem. Acc. 2000, 103, 343.

45. Okulik, N.; Jubert, A. H.; J. Mol. Des. 2005, 4, 17.

46. Parlak, C.; Akgogan, M.; Yildirim, G.; Karagoz, N.; Budak, E.; Terzioglu, C.; Spectrochim. Acta, Part A 2011, 79, 263. 
47. Dassault Systèmes BIOVIA, Discovery Studio Visualizer, Release 2016; Dassault Systèmes, San Diego, 2016.

48. Klayman, D. L.; Bartosevich, J. F.; Griffin, T. S.; Mason, C. J.; Scovil, J. P.; J. Med. Chem. 1979, 22, 855.

49. Frisch, M. J.; Trucks, G. W.; Schlegel, H. B.; Scuseria, G. E.; Robb, M. A.; Cheeseman, J. R.; Scalmani, G.; Barone, V.; Petersson, G. A.; Nakatsuji, H.; Li, X.; Caricato, M.; Marenich, A.; Bloino, J.; Janesko, B. G.; Gomperts, R.; Mennucci, B.; Hratchian, H. P.; Ortiz, J. V.; Izmaylov, A. F.; Sonnenberg, J. L.; Williams-Young, D.; Ding, F.; Lipparini, F.; Egidi, F.; Goings, J.; Peng, B.; Petrone, A.; Henderson, T.; Ranasinghe, D.; Zakrzewski, V. G.; Gao, J.; Rega, N.; Zheng, G.; Liang, W.; Hada, M.; Ehara, M.; Toyota, K.; Fukuda, R.; Hasegawa, J.; Ishida, M.; Nakajima, T.; Honda, Y.; Kitao, O.; Nakai, H.; Vreven, T.; Throssell, K.; Montgomery, J. A.; Peralta Jr., A. E.; Ogliaro, F.; Bearpark, M.; Heyd, J. J.; Brothers, E.; Kudin, K. N.; Staroverov, V. N.; Keith, T.; Kobayashi, R.; Normand, J.; Raghavachari, K.; Rendell, A.; Burant, J. C.; Iyengar, J.;
Tomasi, S. S.; Cossi, M.; Millam, J. M.; Klene, M.; Adamo, C.; Cammi, R.; Ochterski, J. W.; Martin, R. L.; Morokuma, K.; Farkas, O.; Foresman, J. B.; Fox, D. J.; Gaussian 09, Revision E.01; Gaussian, Inc., Wallingford, 2009.

50. Merrick, J. P.; Moran, D.; Radom, L.; J. Phys. Chem. A 2007, $111,11683$.

51. Jamroz, M. H.; Vibrational Energy Distribution Analysis VEDA 4; SMMG, Warsaw, 2004.

52. Frisch, A.; Nielsen, A. B.; Holder, A. J.; GaussView User Manual; Gaussian, Inc.: Pittsburgh, 2001.

53. Michel, F. S.; J. Mol. Graphics Modell. 1999, 17, 57.

54. Morris, G. M.; Huey, R.; Lindstrom, W.; Sanner, M. F.; Belew, R. K.; Goodsell, D. S.; Olson A. J.; J. Comput. Chem. 2009, 16,2785 .

Submitted: January 17, 2018

Published online: May 18, 2018 